\title{
Generation of Leukotrienes by Purified Human Lung
}

\section{Mast Cells}

\author{
Donald W. MacGlashan, Jr., Robert P. Schleimer, Stephen P. Peters, \\ Edward S. Schulman, G. Kenneth adams III, Harold H. Newball, and \\ LaWrence M. LiChtENSTEIN, The Johns Hopkins University, Department of \\ Medicine, Division of Clinical Immunology, Good Samaritan Hospital, \\ Baltimore, Maryland 21239
}

A B S T R A C T Although mediator release from mast cells and basophils plays a central role in the pathogenesis of human allergic disease, biochemical studies have been restricted to rat peritoneal mast cells and basophilic leukemia cells because they could be easily purified. We have used two new techniques of cell separation to purify human lung mast cells to $98 \%$ homogeneity. Lung cell suspensions were obtained by dispersion of chopped lung tissue with proteolytic enzymes. Mast cells were then purified from the suspensions by countercurrent centrifugal elutriation and affinity chromatography. The purified mast cells released both histamine and slow-reacting substance of anaphylaxis (SRS-A) (leukotriene C and D) during stimulation with goat anti-human IgE antibody. Moreover, these preparations were able to generate significant quantities of SRS-A $\left(32 \pm 7 \times 10^{-17}\right.$ LTD moleequivalents/mast cell) at all stages of purification, indicating that a secondary cell is not necessary for the antigen-induced release of SRS.

\section{INTRODUCTION}

Studies of respiratory allergic disease using chopped lung fragments have provided substantial insight into the mechanisms of mediator release by antigenic stimuli (1). This system was modified by Lewis et al. (2) who introduced techniques to disperse the tissue into single cell suspensions using the proteases elastase, collagenase, chymopapain, and pronase. Single cell suspensions have allowed many manipulations that were tedious or impractical with chopped lung fragments. Lewis et al. (2) have also partially purified mast cells using isokinetic and isopycnic gradients. These tech-

Address reprint requests to Dr. Lichtenstein.

Received for publication 19 March 1982 and in revised form 30 June 1982. niques, however, only rarely resulted in mast cell purities $>60 \%$, which precluded many biochemical studies. We have developed an alternative procedure that uses the enzymatic dispersion of tissue followed by two newer techniques of cell separation that allow mast cells to be recovered at purities of $>98 \%$. We demonstrate here that the highly purified cells release both histamine and slow-reacting substance of anaphylaxis (SRS-A $)^{1}$ when challenged with either antigen or antiIgE antibody. Furthermore, we demonstrate that the purified human mast cells can generate significant quantities of SRS-A without the cooperation of accessory cells.

\section{METHODS}

Buffers. PAG; $25 \mathrm{mM}$ piperazine- $N, N^{\prime}$-bis-2-ethanesulfonic acid (PIPES) (Sigma Chemical Co., St. Louis, MO), 140 $\mathrm{mM} \mathrm{NaCl}, 6 \mathrm{mM} \mathrm{KCl}, 0.003 \%$ human serum albumin (Miles Laboratories, Inc., Ekhart, IN), 0.1\% glucose. PAGCM; PAG with $1 \mathrm{mM} \mathrm{CaCl}_{2}$ and $1 \mathrm{mM} \mathrm{MgCl}$. TGD; Tyrode's buffer$140 \mathrm{mM} \mathrm{NaCl}, 2.7 \mathrm{mM} \mathrm{KCl}, 0.4 \mathrm{mM} \mathrm{NaH} \mathrm{PO}_{4}, 2.2 \mathrm{mM}$ $\mathrm{CaCl}_{2}, 1.1 \mathrm{mM} \mathrm{MgCl}, 0.1 \%$ glucose, $10 \mathrm{mg} / \mathrm{ml}$ deoxyribonuclease type $\mathrm{I}$, and $1 \mathrm{~g} /$ /iter gelatin.

Reagents. Goat anti-IgE antibody was the gift of Dr. K. Ishizaka, Johns Hopkins School of Medicine. Leukotriene standards $\left(\mathrm{LTC}_{4}\right.$ and $\mathrm{LTD}_{4}$ ) for the bioassay were kindly provided by Dr. Rokach of Merck-Frosst \& Co., Montreal, Canada.

Mast cell purification. Single cell suspensions of mast cells were obtained by enzymatic dispersion of chopped lung fragments using a modification of the procedure described by Lewis et al. (2). The cell suspensions were further purified by centrifugal elutriation (Beckman JE-6 rotor, Beckman Instruments, Inc., Fullerton, CA; 1825 rpm, flow rates 11$30 \mathrm{ml} / \mathrm{min}$.) that resulted in purities of $15-46 \%$ (mean \pm SEM: $26 \pm 3 \%, n=20$ ). Elutriation (3) is a negative selection pro-

\footnotetext{
${ }^{1}$ Abbreviations used in this paper: BPO-FLYS, N-benzylpenicilloyl $\epsilon-N$ - $\alpha$-formyl-L-lysine; BPO-HSA, $N$-benzylpenicilloyl-1-human serum albumin; PG, prostaglandin; PIPES, piperazine- $N, N^{\prime}$-bis-2-ethanesulfonic acid; SRS-A, slow-reacting substance of anaphylaxis.
} 
cedure that separates cells according to their size; a major advantage of this technique is that cells are exposed only to isotonic buffer during centrifugation. The cells were then passively sensitized with purified penicillin (BPO)-specific IgE antibody $(6,000 \mathrm{ng} / \mathrm{ml})$ as described previously for basophils (4), washed, and loaded onto a penicillin-Sepharose $6 \mathrm{MB}$ column. Most nonmast cells were washed from the column with buffer (4) after which the bound mast cells were eluted from the beads with buffer containing monovalent penicillin (2 $\mathrm{mM} N$-benzylpenicilloyl- $N$-formyl-L-lysine [BPO-FLYS]). The resulting suspensions consisted of $60-98 \%$ mast cells (mean \pm SEM: $81 \pm 3 \%, n=20$ ) that, by several criteria, including dye exclusion and electron microscopy (kindly performed by Dr. Ann Dvorak and Kathryn Pyne), were intact and functional (Fig. 1). A full description of the procedures for mast cell purification will be published elsewhere (5).

Leukotriene release. Mast cells at various stages of purification were suspended in PAGCM so that the mast cell concentration ranged from 1 to $3 \times 10^{6} / \mathrm{ml}$. Usually $200 \mu \mathrm{l}$ of suspension was challenged with either $200 \mu \mathrm{l}$ of control buffer, containing normal goat serum or anti-IgE antibody (quantity as indicated in Table I). After 15-40 min small aliquots were removed for determination $(6,7)$ of histamine release and the reactions stopped by centrifugation and removal of the supernatant. The biological activity of the mast cell supernatant solutions was measured on the terminal segments of guinea pig ileum. Ileal strips were suspended in organ baths containing Tyrode's solution equilibrated with $\begin{array}{lllll}95 \% & \mathrm{O}_{2}-5 \% & \mathrm{CO}_{2} & \text {. The buffer contained atropine sulfate }\end{array}$ (Sigma Chemical Co.) $\left(5 \times 10^{-7} \mathrm{M}\right)$ and diphenhydramine (Sigma Chemical Co.) $\left(10^{-6} \mathrm{M}\right)$. Contractions were measured with Grass FT03C force-displacement transducers and were recorded on a Grass polygraph (Grass Instrument Co., Quincy, MA). Leukotriene standards were used to establish a calibration curve in each experiment. Results were calculated as LTD equivalents. In preliminary experiments with atropinized ileum in the absence of an antihistamine, we found that a standard unit of LTD activity (contraction equal to that by $5 \mathrm{ng} / \mathrm{ml}$ histamine) was achieved with $\sim 2 \mathrm{pmol} \mathrm{LTD} / \mathrm{ml}$, although this value was somewhat variable. Two ileal segments were studied simultaneously.

LTC and LTD measurements were also made by a radioimmunoassay (RIA) developed by Dr. Hayes and Dr. Rosenthal of the Merck Research Institute (submitted for publication). This RIA uses a rabbit antibody, having a titer of $\sim 1: 25,000$, which is specific for leukotrienes $C$ and $D$ with slight cross-reactivity with LTE. Concentrations of leukotrienes that produce $50 \%$ inhibition of binding are $7,12.5$, and $100.5 \mathrm{pmol} / \mathrm{ml}$ for $\mathrm{LTC}_{4}, \mathrm{LTD}_{4}$, and $\mathrm{LTE}_{4}$, respectively. Arachidonic acid, prostaglandin $\mathrm{F}_{2 \alpha}\left(\mathrm{PGF}_{2 \alpha}\right)$, prostaglandin $\mathrm{E}_{2}\left(\mathrm{PGE}_{2}\right)$, and glutathione cross-react $<10 \%$ at $7 \mathrm{nmol} / \mathrm{ml}$ and 5-hydroxy eicosatetranoic acid and fully reduced $\mathrm{LTC}_{4}$ cross-react $<5 \%$ at $0.7 \mathrm{nmol} / \mathrm{ml}$. The radiolabel was a tritiated $\mathrm{LTC}_{4}$ and unlabeled standard was provided by $\mathrm{Dr}$. Rokach. Although all the data shown in the results section were derived from assays of SRS-A activity on the ileum approximately half of the samples were also run in the RIA to confirm these results.

\section{RESULTS}

Mast cells of purities up to $98 \%$ were examined for their ability to release histamine and SRS-A. Fig. 2 shows a tracing of the response of guinea pig ileum

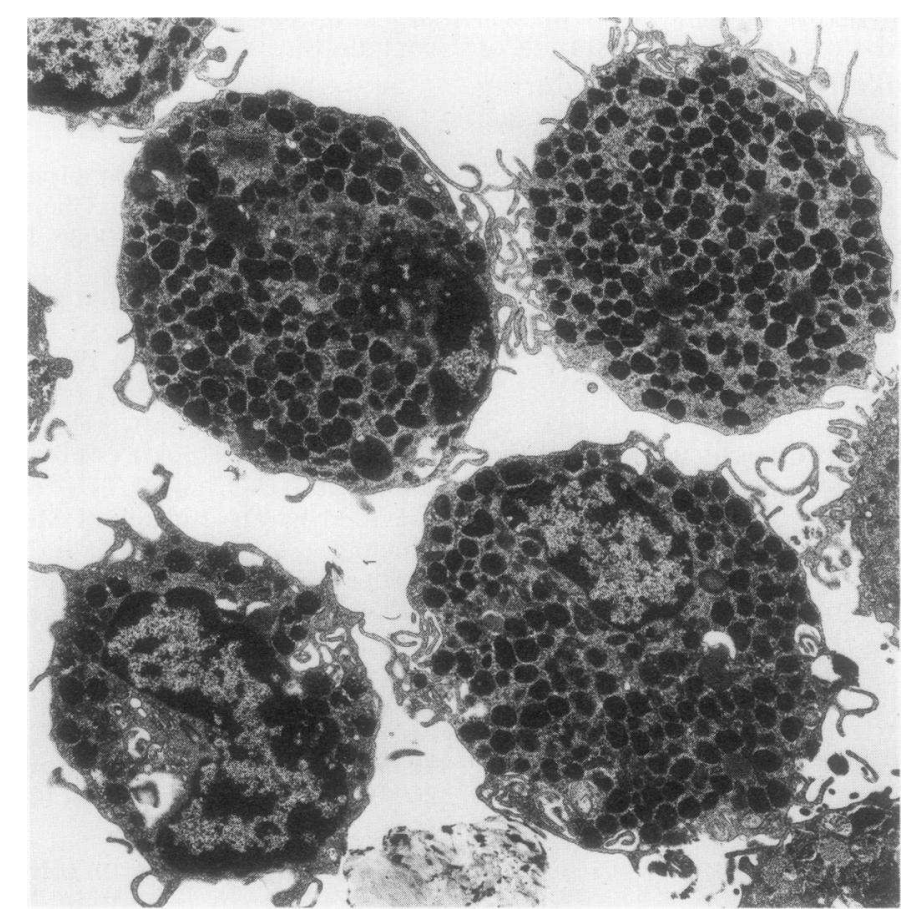

FIGURE 1 Electron micrograph of purified human lung mast cells processed with collidinebuffered osmium tetroxide and uranyl en bloc. Grid lightly stained with lead citrate. $\times 5000$. 


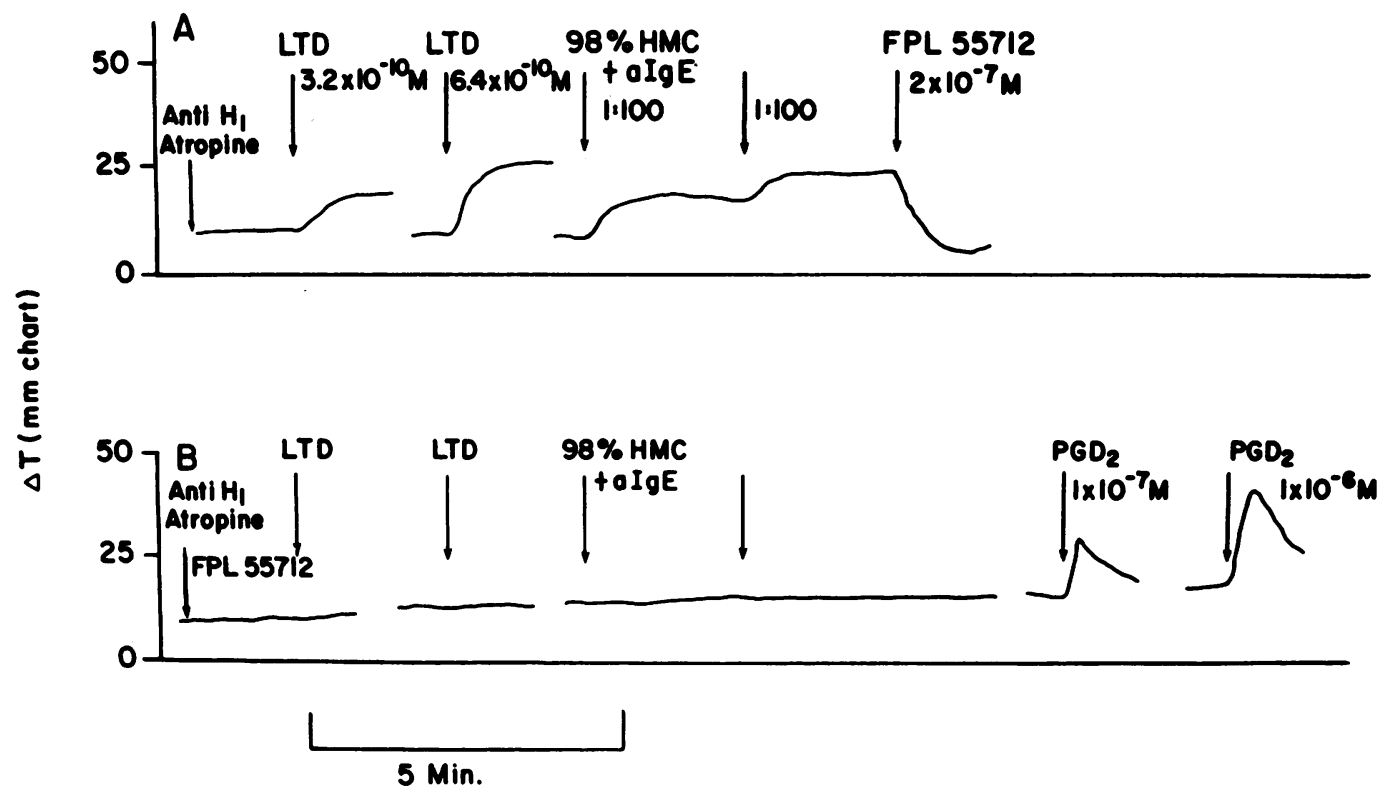

Figure 2 Two tracings of guinea pig ileum contractions in response to leukotriene standards and mast cell supernatants. The strip in tracing $A$ was pretreated with atropine and diphenhydramine, while the strip in tracing $B$ was pretreated with atropine, diphenhydramine, and FPL 55712. HMC, human mast cell.

to either $98 \%$ pure mast cell supernatants (stimulated with anti-IgE antibody) or to synthetic leukotriene D standards. Note that the ileum treated with an SRS-A antagonist, FPL 55712, remained responsive to prostaglandin $\mathrm{D}_{2}\left(\mathrm{PGD}_{2}\right) \cdot 10^{-7} \mathrm{M}$ concentrations of $\mathrm{PGD}_{2}$ can result from antigen stimulation of mast cells in these preparations, but diluted 1:100 in the ileal bath this concentration produced no contraction. In $13 \mathrm{ex}$ periments with mast cells ranging from 61 to $98 \% \mathrm{pu}$ rity, histamine release averaged $40 \pm 5 \%$ (spontaneous release of 5\%) and the average quantity of LTD equivalents generated was $32 \pm 7 \times 10^{-17} \mathrm{~mol} /$ mast cell; the amount produced by different mast cell preparations varied 40-fold (Table I). The anti-IgE antibody dose response of SRS-A release paralleled that for histamine release (data not shown). In experiment 9 the mast cells were challenged with the antigen, $N$-benzylpenicilloyl-human serum albumin (BPO-HSA), at a concentration optimal for histamine release. In this same experiment we found that cells desensitized with BPOHSA $(8,9)$ failed to release either histamine or SRS-A upon rechallenge with BPO-HSA (data not shown).

In the four experiments shown in the bottom half of Table I, mast cells from the same lung were challenged at various stages of purification. In each case the production of LTD-equivalents/mast cell was not influenced by the presence of other cell types; i.e., preparations of mast cells at low purity produced no more SRS than highly purified mast cells. In experi-
TABLE I

SRS-A Release from Purified Mast Cells

\begin{tabular}{|c|c|c|c|c|}
\hline Experiment & Purity & Stimulus ${ }^{\circ}$ & $\begin{array}{l}\text { Histamine } \\
\text { release }\end{array}$ & $\begin{array}{l}\text { LTD equivalents } \\
\text { generated } t\end{array}$ \\
\hline & $\%$ & & $\%$ & \\
\hline 1 & 98 & 10 & 46 & 1.7 \\
\hline 2 & 85 & 1 & 57 & 67 \\
\hline 3 & 98 & 1 & 56 & 30 \\
\hline 4 & 88 & 1 & 61 & 30 \\
\hline 5 & 61 & 3 & 41 & 46 \\
\hline 6 & 65 & 3 & 26 & 42 \\
\hline 7 & 97 & 3 & 63 & 59 \\
\hline 8 & 88 & 3 & 60 & 37 \\
\hline 9 & 75 & $100 \$$ & 10 & 1.7 \\
\hline \multirow[t]{2}{*}{10} & 12.5 & 10 & 6 & 1.1 \\
\hline & 75 & 10 & 17 & 1.7 \\
\hline \multirow[t]{2}{*}{11} & 7.5 & 3 & 17 & 19 \\
\hline & 92 & 3 & 38 & 33 \\
\hline \multirow[t]{2}{*}{12} & 33 & 0.3 & 19 & 1.8 \\
\hline & 94 & 0.3 & 22 & 2.4 \\
\hline \multirow[t]{2}{*}{13} & 3.7 & 1 & 30 & 5.4 \\
\hline & 85 & 1 & 23 & 60 \\
\hline
\end{tabular}

- Challenged with anti-IgE antibody at the doses shown, in $\mu \mathrm{g} / \mathrm{ml}$. t Results expressed as LTD mole equivalents per mast cell $\times 10^{17}$. $\$$ Challenged with $100 \mathrm{ng} / \mathrm{ml} \mathrm{BPO}{ }_{21}-\mathrm{HSA}$.

The doses of anti-IgE were predetermined to be optimal for histamine release. Controls (buffer challenge) were also tested in each experiment; spontaneous histamine release was $<5 \%$ and there was no detectable spontaneous SRS-A release (data not shown in table). 
ments 10-12 the impure cells had not been passively sensitized before challenge (in contrast to purified cells that must be sensitized to be affinity purified) and histamine release was found to be slightly lower. We therefore repeated those experiments but also sensitized the low purity cells. In experiment 13 we found that purified cells release, if anything, more SRS-A than impure cells.

In 17 experiments ( 13 unrelated to the experiments in Table I) the ratio of LTC/D concentrations determined by RIA and those determined by the bioassay was $1.15 \pm 0.14$. For example the values determined by RIA for supernatants from experiments $7,9,11$ a and b were 54, 2.7, 19, and 33 LTD mole-equivalents/mast cell. Furthermore, all supernatants that had undetectable concentrations of LTD (controls and nonreleasing preparations) as determined by the bioassay also had undetectable or very low values by the RIA.

\section{DISCUSSION}

The contractile response of airways to antigenic challenge results not only from the release of histamine from mast cells but also from the generation of lipoxygenase products of arachidonic acid, principally leukotrienes C and D (SRS-A) (10), by cells that are presently undefined. Whether rat peritoneal mast cells are able to generate SRS is not clear (11-13). With respect to human lung mast cells it has been found that as they are purified by density gradient centrifugation from 5 to $70 \%$ their ability to generate SRS decreases (14). It has therefore been suggested that the production of leukotrienes $\mathrm{C}$ and $\mathrm{D}$ requires a secondary cell, perhaps the interstitial macrophage (14). We found, however, that human lung mast cells do release significant quantities of SRS-A and that the production of LTDequivalents/mast cell did not change as mast cells from the same lung were purified from 3 to $98 \%$. This material is identified as LTC or D based on the characteristics of the ileum contraction curve (slow), the ability of FPL 55712 to inhibit the ileal contraction, and its detectability by an RIA specific for LTC and LTD.

Whether the mast cell generates all of the SRS-A released from antigen-stimulated chopped lung is not clear. Parallel experiments with chopped lung were not performed but chopped lung fragments have been reported to generate 15-20 units of SRS-A/g of tissue (15). Based on the data from $98 \%$ mast cells (experiment 1 in Table $I$ in which the mast cells released the lowest quantity of SRS-A), we calculate that the mast cells $\left(2 \times 10^{6}\right)$ from a gram of lung would produce $>17$ units of SRS-A; it is clear that this is a conservative estimate since using the mean of the experiments in Table I we would get a value of 320 units of SRS-A. Thus, it appears that the mast cell is capable of pro- ducing most or all of the SRS-A released by antigenchallenged chopped human lung. In any event, it is clear that the mast cell does not require an auxiliary cell to produce SRS-A. Our studies do not address the question of the total biosynthetic capability of various pulmonary cells activated with nonantigenic stimuli (such as ionophore, immunoglobulin aggregates, or other agents).

It also appears that leukotrienes represent a significant fraction of the arachidonic acid metabolites generated by mast cells. Purified human lung mast cells release $\sim 50 \mathrm{ng} / 10^{6}$ cells of $\mathrm{PGD}_{2}(16,17)$ and we have determined that of five prostaglandins measured $\mathrm{PGD}_{2}$ represents the major cyclooxygenase metabolite (17). Therefore, PGD $_{2}$ and SRS-A (LTC/D) are generated in approximately equimolar quantities by mast cells (LTC/D; $32 \times 10^{-17}$ LTD mole equivalents per mast cell or $\sim 200 \mathrm{ng} / 10^{6}$ mast cells). Since neither all lipoxygenase or cyclooxygenase arachidonic acid metabolites have been measured, we cannot determine which are the major metabolic pathways.

Because highly purified human mast cells have not been available, mediators generated by antigenic challenge of chopped lung could not be unambiguously assigned to the mast cell. Moreover, direct biochemical studies on human material could not be carried out. Since strategies for the pharmacologic control of the human allergic response must be based on an appreciation of the release mechanism and the source of various mediators, the availability of highly purified human mast cells may be expected to have important consequences.

\section{ACKNOWLEDGMENT}

This work was supported in part by National Institutes of Health grants AI 07290 and HL 23586.

\section{REFERENCES}

1. Sheard, P., P. Killingback, and A. M. J. N. Blair. 1967. Antigen-induced release of histamine and SRS-A from human lung passively sensitized with reaginic serum. Nature (Lond.). 216: 283.

2. Lewis, R. A., S. I. Wasserman, J. W. Said, and K. F. Austen. 1976. Release of chemical mediators from partially purified human lung mast cells. J. Immunol. 117: 1356-1362.

3. Pretlow, T. G., and T. P. Pretlow. 1975. Centrifugal elutriation (counterstreaming centrifugation) of cells. Cell Biophys. 1: 195-210.

4. MacGlashan, D. W., Jr., and L. M. Lichtenstein. 1980. The purification of human basophils. J. Immunol. 124: 2519-2521.

5. Schúlman, E. S., D. W. MacGlashan, Jr., S. P. Peters, R. P. Schleimer, H. H. Newball, and L. M. Lichtenstein. Human lung mast cells: purification and characterization. In press.

6. Siraiganian, R. P. 1974. An automated continuous flow 
system for the extraction and fluorometric analysis of histamine. Anal. Biochem. 57: 383-394.

7. Lichtenstein, L. M., and A. G. Osler. 1964. Studies on the mechanisms of hypersensitivity phenomena: histamine release from human leukocytes by ragweed pollen antigen. J. Exp. Med. 120: 507-530.

8. Lichtenstein, L. M. 1971. The immediate allergic response: in vitro separation of antigen activation, decay, and histamine release. J. Immunol. 107: 1122-1129.

9. MacGlashan, D. W., Jr., and L. M. Lichtenstein. 1981 The transition from specific to nonspecific desensitization in human basophils. J. Immunol. 127: 2410-2414.

10. Dahlen, S. E., P. Hedqvist, S. Hammarstrom, and B. Samuelsson. 1980. Leukotrienes are potent constrictors of human bronchi. Nature (Lond.). 288: 484-486.

11. Bach, M. R., and J. R. Brashler. 1978. Ionophore A23187induced production of slow reacting substance of anaphylaxis (SRS-A) by rat peritoneal cells in vitro: evidence for production by mononuclear cells. I. Immunol. 120: 998-1005.

12. Orange, R. P., E. G. Moore, and E. W. Gelford. 1980. The formation and release of slow reacting substance of anaphylaxis by rat and mouse peritoneal mononuclear cells induced by ionophore A23187. J. Immunol. 124: 2264-2267.

13. Yecies, L. D., H. L. Wedner, S. M. Johnson, B. A. Jakschik, and C. W. Parker. 1979. Slow reacting substance (SRS) from ionophore A23187 stimulated peritoneal mast cells of the normal rat. I. Conditions of generation and initial characterization. J. Immunol. 122: 20832089.

14. Lewis, R. A., J. M. Drazen, E. J. Corey, and K. F. Austen. 1981. In SRS-A and Leukotrienes. P. Piper, editor. John Wiley \& Sons, Ltd., Chichester. 101-107.

15. Lewis, R. A., S. I. Wasserman, E. J. Goetzl, and K. F. Austen. 1974. Formation of slow reacting substance of anaphylaxis in human lung tissue and cells before release. J. Exp. Med. 140: 1133-1146.

16. Lewis, R. A., S. J. Holgate, L. J. Roberts II, J. A. Oates, and K. F. Austen. 1981. Preferential generation of prostaglandin $\mathrm{D}_{2}$ by rat and human mast cells. In Biochemistry of Acute Allergic Reactions. Alan R. Liss, Inc., New York. 239-254.

17. Schleimer, R. P., D. W. MacGlashan, Jr., E. S. Schulman, S. P. Peters, N. F. Adkinson, H. H. Newball, G. K. Adams, and L. M. Lichtenstein. 1982. Effects of glucocorticoids on mediator release from human basophils and mast cells. Fed. Proc. 41: 487a. 